\title{
Günü Geçmiş Bisküvinin Koi Havuz Sazanı (Cyprinus carpio) Yavru Diyetlerinde Mısır Unu Yerine Karbonhidrat Kaynağı Olarak Kullanımı*
}

\author{
Mehmet ORUÇ ${ }^{1 * *}$, Fatma Nida ÇOBAN ${ }^{1}$, Hakan Murat BÜYÜKÇAPAR ${ }^{1}$ \\ ${ }^{1}$ KSÜ, Ziraat Fakültesi, Su Ürünleri Bölümü, Kahramanmaraş
}

Geliş (Received): 08.02.2016

Kabul (Accepted): 04.04.2016

\begin{abstract}
ÖZET: Günü geçmiş bisküvinin koi havuz sazanı (Cyprinus carpio) yavrularının pratik diyetlerinde karbonhidrat kaynağı olarak kullanılabilirliğini belirlemek için laboratuvar koşullarında, 60 günlük besi denemesi yürütülmüştür. Günü geçmiş bisküvi diyetlere $\% 0,25,50,75,100$ oranında katılmıștır $\left(\mathrm{D}_{0}, \mathrm{D}_{1}, \mathrm{D}_{2}, \mathrm{D}_{3}, \mathrm{D}_{4}\right)$. Denemede büyüme parametreleri bakımından $\mathrm{D}_{1}, \mathrm{D}_{2}, \mathrm{D}_{3}$ diyet grupları ile $\mathrm{D}_{0}$ grupları arasında fark benzer bulunurken $(\mathrm{P}>0.05), \mathrm{D}_{4}$ grubu diğer gruplara göre önemli derecede yüksek bulunmuştur $(\mathrm{P}<0.05)$. Sonuç olarak, günü geçmiş bisküvi koi havuz sazan yemlerinde alternatif yem katk1 maddesi potansiyeline sahiptir ve herhangi bir olumsuz etkisi olmaksızın rasyonlara \%100'e kadar katılabilir.
\end{abstract}

Anahtar Kelimeler: Günü geçmiş bisküvi, Karbonhidrat, Koi sazanı, Cyprinus carpio, Büyüme

\section{Use of Expired Biscuit as Carbohydrate Sources instead of Maize in Diets of Fingerlings of Koi Carp (Cyprinus carpio)}

\begin{abstract}
A 60 day laboratory growth trial was carried out to determine the potential nutritional value of expired biscuit as a dietary carbohydrate source of koi carp (Cyprinus carpio) fingerlings. Expired biscuit was included in the diets at different levels $0 \%, 25,50,75,100\left(\mathrm{D}_{0}, \mathrm{D}_{1}, \mathrm{D}_{2}, \mathrm{D}_{3}\right.$, and $\mathrm{D}_{4}$ respectively). On the basis of the observed growth parameters $D_{0}, D_{1}, D_{2}, D_{3}$ diets were similar $(P>0.05)$. but $D_{4}$ were significantly $(P<0.05)$ higher than those of fed on the other groups $\left(\mathrm{D}_{0}, \mathrm{D}_{1}, \mathrm{D}_{2}, \mathrm{D}_{3}\right)$. Results showed that expired biscuit had potential as an alternative feed ingredient in diets for fingerling koi carp (Cyprinus carpio) with no adverse effects. Expired biscuit can be used up to $100 \%$ as a carbohydrate source.
\end{abstract}

Key Words: Expired biscuit, Koi carp, Carbohydrate, Cyprinus carpio, Growth

\section{GíRIş}

Balık yetiştiriciliğinde yem maliyetini azaltmanın ve sektörün sürdürülebilirliğini sağlamanın temel kuralı, yemlerde kullanılan ham maddelerin maliyetini düşürmektir. $\mathrm{Bu}$ da alternatif enerji ve protein kaynaklarını bulmak ve balıklar için uygun dozları saptamakla olabilir. Hayvancılığın hızla gelişmesi ile birlikte yem kaynaklarının da yoğun olarak kullanımı, balık yemlerinde kullanılan besin maddelerinin (misır, soya fasulyesi gibi) fiyatlarında artışlara neden olmuştur. (Siddhuraju ve Becker, 2002). Yem problemi çözüme kavuşturulmadıkça ucuz balık üretmek ve tüketmek mümkün olmayacaktır. Konuyla ilgili daha önce yapılan bilimsel çalışmalarda genellikle balık diyetlerinde alternatif protein kaynakları üzerine çalışılmıştır (Webster ve ark., 1997; Olvera ve ark., 2002; Büyükçapar ve Kamalak, 2006; Abbas ve ark., 2008; Büyükçapar ve Kamalak, 2010; Büyükçapar, 2012; Yiğit ve ark., 2013). Buna karşın karbonhidrat kaynağı olabilecek yem kaynaklarının kullanımı ile ilgili çalışmalar yetersiz kalmıştır. Genel olarak balık diyetlerinde karbonhidrat kaynaklarını kullanımı yetersizdir (Shiau, 1997). Karbonhidratlar enerji kaynağı olarak ve bağlayıcı özelliklerinden dolayı kullanım miktarına dikkat edildiği sürece balıklar tarafindan verimli bir şekilde kullanabilmektedir (Krogdahl ve ark., 2005). Bir tahıl ürünü olan mısır unu birçok yemin yapımında yoğun olarak kullanılan bir karbonhidrat kaynağ olduğundan misır unu zaman zaman pahalı ve sinırlı bir kaynak olabilmektedir. Bu açıdan ucuz ve kolay bulunabilen bitkisel ve işlenmiş endüstriyel kaynakların kullanılması ekonomik açıdan büyük önem taşımaktadır. Bunun yanında insan gıdası olarak belirli işlemlerden geçirilerek üretilen gıdalardan günü geçmiş ürünlerin tekrar ekonomiye kazandırılması anlamında, balık beslemede kullanımları üzerine araştırmalar çok yetersiz kalmıştır. Araştırmaya konu olan günü geçmiş bisküvinin bir şekilde tekrar ekonomiye kazandırılması gerekmektedir. Bisküvinin balık diyetlerinde kullanılması gerek bisküvi üretim sektörüne gerekse balık yemi sektörüne farklı alternatifleri sunacaktır.

$\mathrm{Bu}$ araştırmada marketten temin edilen ve un haline getirilen günü geçmiş bisküvi, koi havuz sazanı diyetlerinde karbonhidrat kaynağı olarak kullanılan mısır unu yerine katılmıştır. Bu hazırlanan diyetlerle koi havuz sazan (Cyprinus carpio) yavruları beslenerek, büyüme parametreleri incelenmiştir.

\section{MATERYAL VE METOT}

\section{Diyet hazırlama}

Günü geçmiş çeşitli bisküvi türleri (tuzlu, şekerli) marketten temin edilmiştir. Temin edilen günü geçmiş bisküviler öğütülerek un haline getirilmiştir. Diyetlere günü geçmiş bisküvi unu ham olarak $(\% 0,25,50,75$, 100) katılmıştır. Günü geçmiş bisküvi unu, balık unu,

\footnotetext{
* Bu çalışma KSÜ BAP tarafindan desteklenen 2014/4-1 nolu yüksek lisans projesinden elde edilmiştir.

**Sorumlu yazar: Oruç, M., mehmet_90_oruc@ hotmail.com
} 
soya küspesi ve mısır ununun kimyasal kompozisyonları ile aminoasit içerileri Çizelge 2.1.'de, deneme

rasyonları ise Çizelge 2.2.'de verilmiştir. Günü geçmiş bisküvinin yağ asit içerikleri Çizelge 2.3.’deki gibidir.

Çizelge 2.1. Karma yemlere katılan günü geçmiş bisküvi, balık unu, mısır unu ve soya küspesinin kuru maddedeki kimyasal kompozisyonu ve aminoasit içerikleri

\begin{tabular}{|c|c|c|c|c|}
\hline Besin Birleşenleri (g/kg) & Balık unu & Soya küspesi & Misir unu & Bisküvi \\
\hline Ham Protein & 701.6 & 470.0 & 78.0 & 70 \\
\hline Ham Yağ & 110 & 10 & 35.2 & 80 \\
\hline Ham Kül & 135.0 & 60.0 & 55.2 & 40 \\
\hline Ham Selüloz & 5.0 & 60.0 & 26.0 & 10 \\
\hline Kuru Madde & 900.6 & 890.0 & 881.3 & 950 \\
\hline Toplam enerji(MJ/kg)* & 21.3 & 17.5 & 16.21 & 17.88 \\
\hline \multicolumn{5}{|c|}{ Esansiyel aminoasitler (g/kg) } \\
\hline Fenilalanin & 32.05 & 22.28 & 3.38 & 2.67 \\
\hline Histidin & 17.46 & 26.39 & 4.78 & 0.56 \\
\hline İzolösin & 36.61 & 22.7 & 2.35 & 2.34 \\
\hline Lösin & 59.05 & 29.84 & 5.9 & 3.93 \\
\hline Metiyonin & 21.17 & 4.46 & 1.22 & 0.23 \\
\hline Treonin & 29.95 & 19.09 & 2.68 & 4.91 \\
\hline Lizin & 67.52 & 27.82 & 2.79 & 1.55 \\
\hline Valin & 39.70 & 24.05 & 3.17 & 2.18 \\
\hline Triptofan & & & & 0.48 \\
\hline \multicolumn{5}{|c|}{ Esansiyel olmayan aminoasitler (g/kg) } \\
\hline Alanin & 42.58 & 22.49 & 4.67 & 5.68 \\
\hline Aspartik asit & 100.81 & 57.82 & 9.79 & 3.55 \\
\hline Prolin & 31.57 & 24.69 & 4.06 & 3.61 \\
\hline Glutamik asit & 92.89 & 76.17 & 11.06 & 22.52 \\
\hline Serin & 25.9 & 25.71 & 3.52 & 1.48 \\
\hline Glisin & 33.59 & 19.68 & 2.81 & 2.19 \\
\hline Tirozin & & & & 1.3 \\
\hline Arjinin & & & & 1.37 \\
\hline
\end{tabular}

\footnotetext{
*Hesaplanmış değer; toplam enerji balık unu için $23.6 \mathrm{kj} / \mathrm{g}$, ham yağ için $39.5 \mathrm{kj} / \mathrm{g}$ ve karbonhidrat için ise $17.2 \mathrm{kj} / \mathrm{g}$ değerlerinden yararlanarak hesaplanmıştır (NRC,1993).
}

Denemede kullanılan rasyonların enerji ve protein oranları dengelenmiştir. Rasyonları oluşturan bütün birleşenler mikserde karıştırıldıktan sonra \%30 su katılarak hamur haline getirilmiștir. Daha sonra et makinesinin 2 no'lu eleğinden geçirilerek pelet haline getirilen diyetler 550C'de 12 saat etüvde kurutulmuştur. Balıklar tartım ve ölçüm yapmadan bir gün önce aç bırakılmış olup 20 günlük arayla diyet gruplarındaki bütün balıkların ağırlıkları tartılmıştır. 
Çizelge 2.2. Deneme rasyonlarının formülasyonu, besin bileşenleri ve aminoasit kompozisyonu

\begin{tabular}{|c|c|c|c|c|c|}
\hline \multirow[t]{2}{*}{ Diyet birleşenleri (g/kg) } & $\mathbf{D}_{0}$ & $\mathbf{D}_{1}$ & $\mathbf{D}_{2}$ & $\mathbf{D}_{3}$ & $\mathbf{D}_{4}$ \\
\hline & $\% 0$ & $\% 25$ & $\% 50$ & $\% 75$ & $\% 100$ \\
\hline Balık unu & 350 & 350 & 350 & 350 & 350 \\
\hline Soya küspesi & 250 & 250 & 250 & 250 & 250 \\
\hline Bisküvi & 0 & 75 & 150 & 225 & 300 \\
\hline Misir unu & 300 & 225 & 150 & 75 & 0 \\
\hline Ayçiçek yağı & 89 & 89 & 89 & 89 & 89 \\
\hline $\mathrm{DCP}^{1}$ & 1 & 1 & 1 & 1 & 1 \\
\hline Vit-Min ${ }^{2}$ & 5 & 5 & 5 & 5 & 5 \\
\hline Tuz & 1 & 1 & 1 & 1 & 1 \\
\hline Metiyonin & 2 & 2 & 2 & 2 & 2 \\
\hline Lizin & 2 & 2 & 2 & 2 & 2 \\
\hline Toplam & 1000 & 1000 & 1000 & 1000 & 1000 \\
\hline \multicolumn{6}{|l|}{ Besin birleşenleri (g/kg) } \\
\hline Ham protein & 386 & 386 & 385 & 385 & 384 \\
\hline Ham yağ & 141.66 & 145.03 & 148.41 & 151.78 & 155.16 \\
\hline Ham selüloz & 23.35 & 22.45 & 21.55 & 20.65 & 19.75 \\
\hline Ham kül & 44.1 & 45.2 & 47.2 & 46.3 & 44.2 \\
\hline Kuru madde & 891 & 885.3 & 897.2 & 877.2 & 900.2 \\
\hline Toplam Enerji (MJ/kg) $)^{3}$ & 20.170 & 20.296 & 20.421 & 20.546 & 20.671 \\
\hline \multicolumn{6}{|c|}{ Esansiyel Aminoasitler (g/kg) } \\
\hline Fenilalanin & 17.80 & 17.74 & 17.69 & 17.64 & 17.58 \\
\hline Histidin & 14.14 & 13.82 & 13.50 & 13.19 & 12.87 \\
\hline İzolösin & 19.19 & 19.19 & 19.19 & 19.19 & 19.19 \\
\hline Lösin & 29.89 & 29.74 & 29.60 & 29.45 & 29.30 \\
\hline Metiyonin & 8.89 & 8.81 & 8.74 & 8.66 & 8.59 \\
\hline Treonin & 16.05 & 16.22 & 16.39 & 16.56 & 16.72 \\
\hline Lizin & 31.42 & 31.33 & 31.23 & 31.14 & 31.05 \\
\hline Valin & 20.85 & 20.78 & 20.71 & 20.63 & 20.56 \\
\hline Triptofan & 0 & 0.03 & 0.07 & 0.10 & 0.14 \\
\hline \multicolumn{6}{|c|}{ Esansiyel Olmayan Aminoasitler (g/kg) } \\
\hline Alanin & 21.92 & 22.00 & 22.07 & 22.15 & 22.22 \\
\hline Aspartik asit & 52.67 & 52.20 & 51.73 & 51.27 & 50.80 \\
\hline Prolin & 18.44 & 18.40 & 18.37 & 18.33 & 18.30 \\
\hline Glutamik asit & 54.87 & 55.73 & 56.59 & 57.45 & 58.31 \\
\hline Serin & 16.54 & 16.39 & 16.24 & 16.08 & 15.93 \\
\hline Glisin & 17.51 & 17.41 & 17.42 & 17.38 & 17.33 \\
\hline Tirozin & 0 & 0.09 & 0.19 & 0.29 & 0.39 \\
\hline Arjinin & 0 & 0.10 & 0.20 & 0.30 & 0.41 \\
\hline
\end{tabular}

${ }^{1}$ Di kalsiyum Fosfat

${ }^{2}$ Her 5kg'da bulunan vitamin mineral içerikleri 200.000.000 IU vitamin A, IU vitamin D3, $200.000 \mathrm{mg}$ vitamin E, 12,000 mg vitamin $\mathrm{K}_{3}, 20.000 \mathrm{mg}$ vitamin B1, $30.000 \mathrm{mg}$ vitamin B2, $200.000 \mathrm{mg}$ niyasin, $50.000 \mathrm{mg}$ Capanthothenate, $20.000 \mathrm{mg}$ B6, 50 $\mathrm{mg}$ vitamin B12, $50 \mathrm{mg}$ vitamin B12, $500 \mathrm{mg}$ D-biotin, $1,200 \mathrm{mg}$ folik asit, $200.000 \mathrm{mg}$ vitamin C ve $300.000 \mathrm{mg}$ inositol, $1.200 .000 \mathrm{mg}$ cholin chloride, $40.000 \mathrm{mg}$ mangan, $30.000 \mathrm{mg}$ Çinko, $800 \mathrm{mg}$ Bakır, $1.000 \mathrm{mg}$ iyodin, $150 \mathrm{mg}$ selenyum, 40.000 mg magnezyum bulunmaktadır.

${ }^{3}$ Hesaplanmış değer; toplam enerji balık unu için $23.6 \mathrm{kj} / \mathrm{g}$, ham yă̆ için $39.5 \mathrm{kj} / \mathrm{g}$ ve karbonhidrat için ise $17.2 \mathrm{kj} / \mathrm{g}$ değerlerinden yararlanarak hesaplanmıştır (NRC,1993). 
Çizelge 2.3. Günü geçmiş bisküvinin yağ asit içeriği

\begin{tabular}{|c|c|}
\hline Esansiyel Yağ Asitleri & $\%$ \\
\hline Arachidonic Acid (C20:4n-6) & 0.1845 \\
\hline Palmiteolic Acid (C16:1n-7) & 0.3602 \\
\hline Oleic Acid (C18:1n-9) & 37.0320 \\
\hline Alfa linolenic Acid (C18:3n-3) & 0.4417 \\
\hline Linoleic Acid (C18:2n-6) & 13.1738 \\
\hline Cis-11-Eicosenoic Acid (C20:1n-9) & 0.0245 \\
\hline Cis-11,14,17-Eicosatrienoic Acid (C20:3n-3) & 0.1931 \\
\hline Cis-5,8,11,14,17-Eicosapentaenoic Acid (C20:5n-3) & 0.0793 \\
\hline Cis-11,14-Eicosadienoic Acid (C20:2n-6) & 0.0228 \\
\hline Cis-13.16-Docosadienoic Acid & 0.0327 \\
\hline Nervonic Acid (C24:1n-9) & 0.1003 \\
\hline Esansiyel Olmayan Yağ Asitleri & $\%$ \\
\hline Myristic Acid (C14:0) & 1.0717 \\
\hline Pentadecanoic Acid (C15:0) & 0.0515 \\
\hline Cis-10-Heptadecanoic Acid (C17:1) & 0.0430 \\
\hline Tricosanoic Acid (C23:0) & 0.0249 \\
\hline Palmitic Acid (C16:0) & 40.7259 \\
\hline Heptadecanoic Acid (C17:0) & 0.1124 \\
\hline Stearic Acid (C18:0) & 5.3522 \\
\hline Behenic Acid (C22:0) & 0.0856 \\
\hline Heneicosanoic Acid (C21:0) & 0.0315 \\
\hline Caprylic Acid (C8:0) & 0.0589 \\
\hline Capric Acid (C10:0) & 0.0540 \\
\hline Lauric Acid (C12:0) & 0.6955 \\
\hline Lignoceric Acid (C24:0) & 0.0484 \\
\hline
\end{tabular}

\section{Balık ve akvaryum sistemleri}

Araştırmada kullanılacak koi havuz sazan yavruları özel bir balık üretim tesisinden (Mersin) KSÜ Ziraat Fakültesi Su Ürünleri Bölümü’ne transfer edilmiştir. İşletmeden getirilen koi havuz sazanı yavruları öncelikle $\% 10$ 'luk metilen mavisinde parazitten arındırılmıştır. Getirilen balıklar ortalama 4 g'dan yaklaşık $8 \mathrm{~g}$ olana kadar 250lt'lik fiberglas tanklarda tutulmuştur. Deneme kurulumundan 7 gün önce balıklar tanklardan alınmış boy ve ağırlık ölçümleri yapılarak 80lt'lik akvaryumlara yerleştirilmiştir. Deneme 2 tekerrürlü 5 diyet grubundan oluşmuştur. Balıklar 15 gün boyunca kontrol diyetiyle beslenmiş ve adaptasyonları sağlanmıştır. $\mathrm{Bu}$ süre içinde hasta ve ölen balıklar akvaryumdan uzaklaştırılmıştır. Deneme 60 gün planlanmış olup, balıklar vücut ağırlıklarının \%3'ü oranında doyuncaya kadar beslenmiştir. Deneme başlangıcındaki ağırlıkları yaklaşık 8 g olan balıklardan her akvaryuma 7 adet yerleştirilmiştir. Deneme 2 tekerrürlü olarak yapılmıştır. Her 20 günde bir tartım yapılarak vücut ağırlığına göre verilen yem miktarı artırılmıştır. Akvaryumlarda havalandirma hava motoru ile merkezi olarak sağlanmış, hava hortumu ile eşit dağıtılmıştır. Balıkların konulduğu akvaryumlardaki suyun \%50'si 20 günde bir ve kullanılan filtreler 10 günde bir değiştirilip temizlenmiştir. Akvaryumlarda su kalitesi iç ve diş filtrelerle kontrol altında tutulmuş olup, günlük sıcaklık ve oksijen oranları ölçülüp, $\mathrm{pH}$ oranları ise haftalık olarak ölçülmüştür.

\section{Kimyasal Analizler}

Günü geçmiş bisküvi unu ve diğer besin maddelerinin kimyasal kompozisyonları AOAC (1990)'a göre yapılmıştır. Günü geçmiş bisküvi ununun 
aminoasit ve yağ asit analizleri TUBİTAK MAM tarafindan yapılmıştır.

\section{İstatistik Hesaplamaları}

Denemeye ait araştırma verileri, "Varyans analizi" ve "Duncan çoklu karıştırma testi"nde 0,05 önem düzeyine göre değerlendirilmiş olup söz konusu istatistiksel analizler SPSS paket programında yapılmıştır.

\section{BULGULAR ve TARTISMA}

Deneme boyunca ölçülen oksijen (mg/It), sıcaklık $\left({ }^{\circ} \mathrm{C}\right)$ ve $\mathrm{pH}$ değerlerinin ortalama değerleri sırasıyla; oksijen $\quad 7.74 \pm 0.03 \quad-\quad 7.90 \pm 0.03 \quad \mathrm{mg} / \mathrm{It}, \quad$ sicaklık $21.18 \pm 0.12$ - $21.73 \pm 0.11{ }^{\circ} \mathrm{C}$ ve $\mathrm{pH} 8.26 \pm 0.07$ $8.34 \pm 0.05$ arasında değişmiştir.

Deneme süresince balıklarda yemden kaynaklanan herhangi bir ölüm ve yem reddetme olayı gözlenmemiştir. Çalışmada elde edilen, deneme sonu itibariyle ortalama canlı ağırlık kazancı, spesifik büyüme oranı (SGR) ve yem değerlendirme oranı (YDO), protein etkinlik oranı (PER), kondisyon faktörü (KF) Çizelge 3.1'de gösterilmiş̧ir.

Çizelge 3.1 Deneme sonu itibariyle büyüme parametreleri

\begin{tabular}{llllll}
\hline & $\mathrm{D}_{0} \% 0$ & $\mathrm{D}_{1} \% 25$ & $\mathrm{D}_{2} \% 50$ & $\mathrm{D}_{3} \% 75$ & $\mathrm{D}_{4} \% 100$ \\
\hline Başlangıç ağrı̆ı̆̆ $(\mathrm{g})$ & $8.02 \pm 0.61^{\mathrm{a}}$ & $7.85 \pm 0.74^{\mathrm{a}}$ & $8.10 \pm 0.75^{\mathrm{a}}$ & $7.97 \pm 0.71^{\mathrm{a}}$ & $7.99 \pm 0.74^{\mathrm{a}}$ \\
Final ağırlığı (g) & $18.26 \pm 2.30^{\mathrm{b}}$ & $19.41 \pm 1.60^{\mathrm{b}}$ & $22.53 \pm 3.19^{\mathrm{b}}$ & $23.17 \pm 2.64^{\mathrm{b}}$ & $30.5 \pm 4.67^{\mathrm{a}}$ \\
Canlı ağırlık kazancı (g) & $3.41 \pm 0.49^{\mathrm{c}}$ & $3.85 \pm 0.63^{\mathrm{bc}}$ & $4.81 \pm 0.40^{\mathrm{b}}$ & $5.06 \pm 0.71^{\mathrm{b}}$ & $7.50 \pm 0.87^{\mathrm{a}}$ \\
Yem alımı (g) & $7.15 \pm 0.86^{\mathrm{a}}$ & $7.34 \pm 0.98^{\mathrm{a}}$ & $7.87 \pm 1.13^{\mathrm{a}}$ & $8.03 \pm 1.24^{\mathrm{a}}$ & $8.69 \pm 1.48^{\mathrm{a}}$ \\
YDO & $2.99 \pm 0.83^{\mathrm{a}}$ & $2.82 \pm 0.94^{\mathrm{a}}$ & $2.07 \pm 0.43^{\mathrm{ab}}$ & $2.04 \pm 0.55^{\mathrm{ab}}$ & $1.33 \pm 0.09^{\mathrm{b}}$ \\
PER (\%) & $1.39 \pm 0.40^{\mathrm{b}}$ & $1.56 \pm 0.47^{\mathrm{ab}}$ & $1.79 \pm 0.45^{\mathrm{ab}}$ & $1.89 \pm 0.53^{\mathrm{ab}}$ & $2.46 \pm 0.41^{\mathrm{a}}$ \\
SGR (\%) & $1.37 \pm 0.36^{\mathrm{b}}$ & $1.50 \pm 0.41^{\mathrm{ab}}$ & $1.70 \pm 0.37^{\mathrm{ab}}$ & $1.77 \pm 0.44^{\mathrm{ab}}$ & $2.23 \pm 0.30^{\mathrm{a}}$ \\
KF & $2.42 \pm 0.08^{\mathrm{a}}$ & $2.44 \pm 0.09^{\mathrm{a}}$ & $2.37 \pm 0.13^{\mathrm{a}}$ & $2.52 \pm 0.07^{\mathrm{a}}$ & $2.45 \pm 0.03^{\mathrm{a}}$
\end{tabular}

Her satırda aynı harfle gösterilen ortalamalar istatiksel olarak benzerdir $(\mathrm{P}>0.05)$. YDO = Tüketilen yem miktarı $(\mathrm{g}) / \mathrm{Canl}$ ağırlık artışı $(\mathrm{g}), \mathrm{PER}=$ Canlı ağırlık artışı $(\mathrm{g}) /$ Yemle alınan protein, $\mathrm{SGR}=[(\ln$ periyot sonu ağırlık $(\mathrm{g})$ - ln periyot başı ağırlık (g)) / yemlenen gün sayısı $]$ X 100, KF $=\left[\right.$ Ağılık $\left.(\mathrm{g}) /(\text { Total boy })^{3}(\mathrm{~cm})\right] \mathrm{X} 100$

Başlangıçta ortalama yaklaşıı 8 g civarı olan balıklar, deneme sonunda $30.5 \mathrm{~g}$ ile $18.26 \mathrm{~g}$ arasinda değişmiş olup en çok büyüme $\mathrm{D}_{4}(\% 100)$ gurubunda görünmüştür (Çizelge 3.1). Büyüme parametreleri bakımından genellikle $\mathrm{D}_{0}, \mathrm{D}_{1}, \mathrm{D}_{2}, \mathrm{D}_{3}$ grupları birbirine benzerken $(\mathrm{P}>0.05)$, diğer gruplardan farklı olarak en iyi gelişme $\mathrm{D}_{4}$ grubunda gözlenmiștir $(\mathrm{P}<0.05)$ (Çizelge 3.1).

Mısır unu yerine rasyona katılan bisküvinin \%100' e kadar kullanılması balıklardaki büyüme parametrelerini olumlu şekilde etkilemiş̧ir. Bu durum proteinin etkin bir şekilde kullanılmasına bağlı olarak, besin ve enerji kullanımındaki artıștan kaynaklanmıs olabileceği gibi, rasyonların esansiyel aminoasit bakımından yeterli seviyeye getirilmiş olunmasından da kaynaklanmış olabilir (Çizelge 2.2). Bitkisel besin kaynaklarında bulunan anti besinsel faktörler, proteinlerin balık diyetlerinde kullanılmasını sınırlandırır (Tacon, 1997; Hossain ve ark., 2001). Bu faktörlerin balık gelişimi üzerine etkileri ile ilgili olarak (Olvera ve ark., 1988) bitkisel besin kaynaklarında anti besinsel faktörler, düşük seviyelerde de olsa balık gelişimini etkileyebileceği ileri sürülmüştür. Bu faktörlerin elimine edilebilmesi için kullanılan yöntemlerden biri de tohumun ya 1sitılması ya da otoklavda bekletilmesidir (Grant, 1991). Benzer şekilde sazan diyetlerine culban
(Vicia peregrina) ham şekilde en fazla \% 10 oranında katılabileceği saptanırken bu oran otoklavda bekletilen culban için \%20 olarak rapor edilmiştir (Büyükçapar ve Kamalak, 2006). Yapılan diğer bir araştırmada ise aynalı sazan yavrularının diyetlerine ham ve 1 sıtıllmış olarak yabani bezelye (Pisum elatius)'nin katıldığı çalı̧̧ada, bezelye diyetlere en fazla \%10 ham olarak katılabilirken otoklavda bekletildiğinde bu oran $\% 30$ 'a kadar çıktığı rapor edilmiștir (Büyükçapar ve Kamalak, 2010). Yaptığımız çalışmada bu anti besinsel faktörlerin büyüme üzerine özellikle de bisküvi katılmış rasyonlarda herhangi bir olumsuz etki göstermediği düşünülebilir. Bu durum bisküvinin yapılıș aşamasında bir sıra 1 sıl işlemden geçiriliyor olmasından (Keskin ve ark., 2005) kaynaklanabilir.

Karma yemlerdeki ham selüloz oranı balı̆ğın beslenme şekline göre değișir, karnivor türlerde düşük iken omnivor türlerde daha yüksektir. Bazı araştırmacılar selüloz içeren diyetlerle beslenen balıklarda düşük ağırlık kazancı olduğunu bildirmiş̧ir (Buhler ve Halver, 1961; Leary ve Lovell, 1975; Hilton ve ark., 1983; Anderson ve ark., 1984). Yapılan diğer bir araştırmada ise kabuğu soyulmuş buğdayın selüloz miktarının azaldığı belirtilmiş̧ir (Dönmez ve ark., 2004). Yapmış olduğumuz çalışmada günü geçmiş bisküvinin içerisinde kullanılan buğday kabuğunun 
soyulmuş olmasının selüloz miktarını azaltacağından (Anonim, 2013), araştırmamızda karbonhidrat kaynağı olarak kullanılan günü geçmiş bisküvinin oranı artıkça ham selüloz oranındaki azalmanın büyüme parametrelerini olumlu yönde etkilediği söylenebilir (Çizelge 2.2).

Yapılan bir çalışmada sazanların rasyonunda kullanılan karbonhidrat kaynaklarının, jelatinizasyonun büyümeyi olumlu yönde etkilediği ve bunun sebebinin de bağırsaktaki nişasta sindiriminin hızlanması nedeniyle olabileceği bildirilmiştir (Hernandez ve ark., 1994). Rasyonda kullanılan karbonhidrat kaynaklarının işlenmesi sonucu balıklarda zayıf olan nişasta kullanımı artmaktadır (Özdemir ve Korkut, 2000). Yapmış olduğumuz çalışmada, rasyonda kullandığımız günü geçmiş bisküvi içerisindeki buğday ununun yüksek miktarda nişasta içeriyor olması (Özer, 1998) ve günü geçmiş bisküvinin yapılış aşamasında bir sıra 1sıl işlemden geçiriliyor olması koi havuz sazanlarında büyümeyi olumlu yönde etkilemiş olabilir.

Bir araştırmada gökkuşağı (Oncorhynchus mykiss) alabalığının yemlerindeki esansiyel yağ asitlerinin büyüme üzerine olumlu etkilerinin olduğu bildirilmiştir (Demir, 1997). Yapılan diğer bir çalışmada ise gökkuşağı alabalıklarında, linolenik asidin (18:3n3) büyüme üzerinde büyük etkisi olduğu saptanmıştır (Hoşsu ve ark., 2008). Sazan balığı ile yapılan çalışmalarda ise sazanların esansiyel yağ asitlerinden linoleik aside (18:2n-6) ve linolenik aside (18:3n-3) \%1 oranında ihtiyaç duydukları gözlenmiştir (Satoh, 1991). Sazan balığının besin maddesi ihtiyaçları hesaplanırken yem içerisine yüksek oranda doymamış yağ asidi içeren yağ katılması gerektiğini bildirmiştir (Satoh, 1991; Hoşsu ve Korkut, 1996). Yapmış olduğumuz çalışmada kullandığımız günü geçmiş bisküvinin içerisinde, linoleik asit ve linolenik asit bulunduruyor olması büyümeye olumlu katkı sağlamış olabilir (Çizelge 2.3).

Balıklar çevrelerindeki besin uyaranlarını değişik duyu organları veya donanımlarıyla algılamakta ve buna göre bir beslenme davranışı oluşturmaktadırlar. Tat tercihleri üzerine yapılan çalışmalar sonucunda, tat tercihlerinin hem tat alma duyu sistemi hem de koklamaya ait sinir sisteminden etkilendiği bildirilmiştir (Atema, 1980). Yem alımını olumlu ya da olumsuz olarak etkileyen maddeler, serbest aminoasitler, nükleotidler, organik asitler olarak sınıflandırılabilir (Carr ve Derby, 1986; Zimmer- Faust ve ark, 1988). Balık ununun ağırlıkta olduğu diyetlerde, balık ununun zengin bir aminoasit içeriğine sahip olması nedeniyle yemin balık açısından cazibesi yüksek olduğundan, bu tür diyetlerde balığın yem alımı açısından sorun yaşanmadığı için, içerisine cezbedici maddelerin ilave edilmesi önemli değildir. Ancak yemin maliyetini düşürmek için kullanılan bitkisel protein ve karbonhidrat içerikli kaynakların düşük oranlarında veya ilavesinde, balıkların göstereceği olası olumsuz tat yanıtlarını elemine etmek için yemlere katıldıklarında yem alımını ve tüketimini olumlu yönde etkileyip yemden yararlanmayı arttıran, böylece daha fazla canlı ağırlık kazancı sağlayan yem katkı maddeleri kullanılabilmektedir (Saglio ve ark., 1990; Andron ve Mackie, 1978). Yapılan bir çalışmada bir yaşın altındaki sazanlarda 13 aminoasitin cezbedici etkisi araştırılmış ve sonuçta sazanlar için en etkili cezbedicilerin sistin, asparjin, glutamik asit, treonin ve alanin olduğu belirtilmiştir (Kyuzhalov, 1996). Başka bir çalışmada ise bitkisel protein ağırlıklı koi balıklarının (Cyprinus carpio) yemlerine cezbedici madde olarak betain ilavesinin yem alımı ve büyüme performansı üzerine olumlu etkisi olduğu görülmüştür (Dalkıran, 2008). Yapılan diğer bir araştırmada, yeme cezbedici madde olarak DL-alanin ve betain katkısının, gökkuşağı alabalıklarının (O. mykiss) yem alımını uyardığı ve sonuçta kontrol grubuna göre daha yüksek canlı ağırlık artışına neden olduğu belirtilmiştir (Beklevik ve Polat, 2001). Yapmış olduğumuz çalışmada karbonhidrat kaynağı olarak kullandığımız günü geçmiş bisküvinin içermiş olduğu gluten maddesinin içerisinde sistin, glutamik asit, treonin ve alanin (Dizlek, 2011) gibi cezbedici aminoasitleri bulundurması ve hazırladığımız rasyonun belirli seviyede balık unu içermesi, yem alımını olumlu yönden etkilemiş olabilir.

Günü geçmiş bisküvi koi havuz sazanlarının diyetlerinde kullanılabilecek alternatif bir karbonhidrat kaynağı olup, \%100'e kadar kullanılmasında balıklarda büyüme açısından herhangi bir sakınca yaratmamaktadır. Günü geçmiş bisküvi kolay olarak elde edilebilmesi nedeniyle koi havuz sazanı yavrularının diyetlerinde kullanılabilecek alternatif karbonhidrat kaynaklarından biri olarak nitelendirilebilir. Ancak günü geçmiş bisküvinin sabit bir fiyatı olmadığından ekonomik olarak yem fiyatına etkisi araştırılamamıştır. İleriye dönük çalışmalarda bu konu göz önünde bulundurulmalıdır.

\section{SONUC}

Karbonhidrat kaynağı olarak kullanılan günü geçmiş bisküvi, balık gelişimine olumlu etkide bulunduğundan dolayı günü geçmiş bisküvinin pazarı genişleyerek, hem özel sektör, hem de kamu bazında ekonomiye katma değer sağlayacaktır. Denemede akvaryum kullanılması alabalık gibi ekonomik türlerin kullanılmasını kısıtlamaktadır. Ancak, bu çalıșma her ne kadar omnivor beslenme özelliğine sahip balıklarda yapılsa da karnivor türlere de 1şık tutabilir.

Yapmış olduğumuz çalışma, bitkisel ve işlenmiş endüstriyel kaynakların kullanılmasının örneklerinden biri olacaktır ve gelecekte aynı veya farklı türler ile yapılacak olan çalışmalarda, değişik bitkisel karbonhidrat kaynaklarının mısır ununa alternatif olarak kullanılmasına olanak sağlayacaktır.

$\mathrm{Bu}$ çalışmada koi havuz sazan (Cyprinus carpio) yemlerine günü geçmiş bisküvinin $\% 100$ seviyesine kadar ilave edilebileceği belirlenmiş olup, koi havuz sazan (Cyprinus carpio) yemlerine yüksek oranlarda günü geçmiş bisküvi ilavesi yem tüketimi, büyüme, yem değerlendirme, protein etkinlik oranı gibi değerlerin artmasılyla sonuçlanmıştır. 


\section{KAYNAKLAR}

Abbas, S., Ahmed, I., Hafeez-Ur-Rehman, M., Mateen, A., 2008. Replacement of Fish Meal by Canola Meal in Diets For Major Carps in Fertilized Ponds. Pakistan Veterinary Journal, 28(3): 111-114.

Anderson, J., Jackson, A.J., Matty, A.J., Capper, B.S., 1984. Effects of Dietary Carbohydrate and Fiber on the Tilapia, Oreochromis niloticus (Linn.). Aquaculture, 37(4): 303-314.

Andron, J.W., Mackie, A.M., 1978. Studies on the Chemical Nature of Feeding Stimulants for Rainbow Trout, Salmo gairdneri Richardson. J. Fish Biol., 12(4): 303-310.

Anonim, 2013. T.C. Milli Eğitim Bakanlığı Gıda Teknolojisi Bisküvi Hamuru Hazırlama. http://megep.meb.gov.tr/mte_program_modul/modul ler_pdf/Bisküvi Hamuru Hazırlama.pdf (12.12.2015).

Atema, J., 1980. Chemical Senses, Chemical Signals and Feeding Behaviour in Fishes. In: Fish Behaviour and Its Use in the Capture and Culture of Fishes (eds J.E. Bardach, J.J. Magnuson, R.C. May and J.M. Reinhart). International Center for Living Aquatic Resources Management, Manila, 57-101.

Beklevik, G., Polat, A., 2001. Effects of DL-Alanine and Betaine Supplemented Diets on The Growth and Body Composition of Fingerling Rainbow Trout (Oncorhynchus mykiss, W. 1972). Turkish Journal of Veterinary and Animal Sciences, 25(3): 301-307.

Buhler, D.R., Halver, J.E., 1961. Nutrition of Salmonid Fishes. IX. Carbohydrate Requirements of Chinook Salmon. J. Nutr., 74(3): 307-318.

Büyükçapar, H.M., 2012. Growth Performance and Body Composition in Mirror Carp (Cyprinus carpio) Fed Culban Seed (Vicia peregrina) With Different Heat Treatments. Kafkas Üniversitesi Veteriner Fakültesi Dergisi, 18(3): 389-394.

Büyükçapar, H.M., Kamalak, A., 2006. Raw and HeatTreated Culban (Vicia peregrina) Seed as Protein Source for Mirror Carp (Cyprinus carpio) Fingerlings. S. Afr. J. Anim. Sci., 36(4): 235-242.

Büyükçapar, H.M., Kamalak, A., 2010. Nutritive Value of Wild Pea (Pisum elatius) Seed as a Dietary Protein Source for Fingerlings of Mirror Carp (Cyprinus carpio). The Israeli Journal of Aquaculture, 62(4): 272-280.

Carr, W.E.S., Derby, C.D., 1986. Chemically Stimulated Feding Behavior in Marine Animals. Importance of Chemical Mixtures and Involvement of Mixture Interactions. J. Chem. Ecol., 12: 9891011.

Dalkıran, G., 2008. Bitkisel Protein Ağırlıklı Yemde Betain Kullanımının Koi Balıklarında (Cyprinus carpio L.) Yem Alımı Ve Büyüme Performansı Üzerine Etkisi. Yüksek Lisans Tezi, Ondokuz Mayıs Üniversitesi Fen Bilimleri Enstitüsü, Samsun, 53 s.
Demir, O., 1997. Lipid Kaynakları ve Lipid Düzeyleri Farklı Rasyonların Gökkuşağı Alabalığı (Oncorhynchus mykiss)'nın Büyüme-Gelişme ve Yağ Asidi Bileşimlerine Etkileri. Süleyman Demirel Üniversitesi Fen Bilimleri Enstitüsü Su Ürünleri Mühendisliği Anabilim Dalı Doktora Tezi (yayınlanmamış), Isparta, $72 \mathrm{~s}$

Dizlek, H., 2011. Gluten Oluşumu ve Bunu SinırlayanEngelleyen Etmenler. Electronic Journal of Food Technologies, 6(3): 14-22.

Dönmez, E., Salantur, A., Yazar, S., Taner, A. K. A. R., \& Yıldırım, Y., 2004. Ülkemizde Bulgurun Yeri ve Bulgurluk Çeşit Geliştirme. Tarla Bitkileri Merkez Araştırma Enstitüsü Dergisi, 13(1-2).

Grant, G., 1991. Toxic Substances İn Crop Plants. The Royal Society Of Chemistry, Thomas Graham IIause, Science Park, Cambridge Cb4 4wff, Cambridge, 49-67s.

Hernandez, M., Takeuchi, T., Watanabe, T., 1994. Effect of Gelatinized Corn Meal as a Carbohydrate Source on Growth Performance, Intestinal Evacuation, and Starch Digestion in Carp. Fisheries Science, 60(5): 579-582.

Hilton, J.W., Atkinson, J.I., Slinger, S.J., 1983. Effect of Increased Dietary Fiber on the Growth of Rainbow Trout (Salmo gairdneri). Can. J. Fish. Aquat. Sci., 40(1): 81-85.

Hossain, M.A., Focken, U., Becker, K., 2001. Evaluation of an Unconventional Legume Seed, Sesbania aculeata, as a Dietary Protein Source for Common Carp (Cyprinus carpio). Aquaculture, 198: 129-140.

Hoşsu, B. ve Korkut, A.Y., 1996. Balık Besleme ve Yem Teknolojisi I (Balık besleme fizyolojisi ve kimyas1). Ege Üniv. Su Ürünleri Fak. Yay. No: 50, Ders Kitabı Dizin No: 19, Ege Üniv. Basımevi, Bornova, İzmir, 157s.

Hoşsu, B., Korkut, A.Y., Fırat, A., 2008. Balık Besleme ve Yem Teknolojisi ( Laboratuvar Uygulamaları ve Yem Yapım Teknolojisi) VI.Baskı. E.Ü. Su Ürünleri Fakültesi Yayın No:50, Ders Kitabı No: 19, Yardımcı Kitaplar: 1, İzmir

Keskin, S.Ö., Öztürk, S., Şahin, S., Köksel, H., Sumnu, G., 2005. Halogen lamp-microwave combination baking of cookies European Food Research and Technology, 220(5): 546-551.

Krogdahl, A., Hemre, G.I., Mommsen, T.P., 2005. Carbohydrates in Fish Nutrition: Digestion and Absorption in Postlarval Stages. Aquaculture Nutrition. 11(2): 103-122.

Kyuzhalov, N.B., 1996. Behavioral Reactions of OneSummer-Old Carp (Cyprinus carpio) to Amino Acids. Vopr.-Ikhtiol., 26(6): 1016-1022.

Leary, D.F., Lovell, T., 1975. Value of Fiber in Production-Type Diet for Channel Catfish. Trans. Am. Fish. Sot., 104(2): 328-332. 
NRC, 1993. Nutrient Requirement of Fish. National Academy Press, Washington DC. S, 114.

Olvera, N.M.A., Martinez, P.C.A., Galvan, C.R., Chavez, S.C., 1988. The Use of Seed of the Leguminous Plant (Sesbania grandiflora) as a Partial Replacement of Fish Meal Diets for Tilapia (Oreochromis mossambicus). Aquaculture, 71: 5160.

Olvera, N.M.A., Olivera-Castillo L., Martinez P.C.A., 2002. Sunflower Seed Meal as Protein Source in Diets for Tilapia rendalli (Boulanger, 1896) Fingerlings. Aquaculture Research, 33: 223-229.

Özdemir, A., Korkut, A., Y., 2000. Gökkuşağı Alabalığı (Oncorhynchus mykiss) Beslemesinde Yüksek Enerjili Yemler. Doğu Anadolu Bölgesi IV. Su Ürünleri Sempozyumu, 28-30 Haziran, Erzurum.

Özer, M.S., 1998. Kepekli Ekmeklerin Bazı Niteliklerinin İncelenmesi ve Kalitelerinin İyileştirilmesi Olanakları. Çukurova Üniversitesi, Fen Bilimleri Enstitüsü, Gıda Mühendisliği Anabilim Dalı, Doktora Tezi, Adana, $152 \mathrm{~s}$.

Saglio, P., Fauconneau, B., Blanc, J.M., 1990. Orientation of Carp, Cyprinus carpio L., to Free Amino Acids from Tubifex Extract in an Olfactometer. J. Fish. Biol. 37(6): 887-898.

Satoh, S., 1991. Common carp, Cyprinus carpio. (In Handbook of nutrient requirements of finfish: CRC Press Boca Raton, FL.) 55-67s.

Shiau, S.Y., 1997. Utilization of Carbohydrates in Warmwater Fish-With Particular Reference to Tilapia, (Oreochromis niloticus $\mathrm{x} 0$. Aureus). Aquaculture, 151(1-4): 79-96.
Siddhuraju, P., Becker, K., 2002. Effect of phenolic non-protein amino acid L-dopa (L-3,4dihydroxyphenylalanine) on growth performance, metabolic rates and feed nutrient utilization of common carp (Cyprinus carpio L.). Aquaculture Nutr., 8(1): 69-77.

Tacon, A.G.J., 1997. Fish Meal Replacers: Review of Antinutrients Within Oilseed and Pulses. A Limiting Factor for The Aqua Feed Green Revolution in? : Feeding tommorrow's Fish. Eds. Tacon, A.G.J. and Basurco, B., S, 153-182.

Webster, C.D, Tiu, L.G., Tidwell, J.H., Grizzle, J.M., 1997. Growth and Body Composition of Channel Catfish (Ictalurus punctatus) fed diets Containin Various Percentages of Canola Meal. Aquaculture, 150(1): 103-112.

Yiğit, N.Ö., Dulluç, A., Koca, S.B., Didinen, B.I., 2013. Aynalı sazan (Cyprinus carpio, L. 1758) yemlerinde soya küspesi yerine kanola küspesi kullanımının büyüme ve vücut kompozisyonu üzerine etkisi. Tarım Bilimleri Dergisi-Journal of Agricultural Sciences, 19: 140-147.

Zimmer-Faust, R.K., StanfdI, J.M., Collard, S.B., 1988. A fast, Multi-channel Fiuorometer for Investigating Aquatic Chemoreception and Odor Trails. Limnol. Oceanogr., 33: 1586- 1595. 